J. Gen. Appl. Microbiol., 14, 19-37 (1968)

\title{
CHARACTERISTICS OF ERWINIA HERBICOLA
}

\author{
KAZUO KOMAGATA, YOSHIO TAMAGAWA AND HIROSHI IIZUKA* \\ Central Research Laboratories, Ajinomoto Co., Inc., Kawasaki, Japan \\ and \\ *Institute of Applied Microbiology, University of Tokyo, Tokyo
}

(Received September 6, 1967)

\begin{abstract}
Taxonomic studies were carried out on yellow-pigmented bacteria which were found widely in paddy rice, fruit and other related plant materials, and they were included in Erwinia herbicola on the basis of flagellation and biochemical characteristics. Determination, nomenclature and relation to other allied bacteria of this species were discussed. Taxonomic position of the strains of Pseudomonas perlurida and Ps. trifolii, which were previously reported by the authors, was corrected.
\end{abstract}

Since the work of DÜGGELI (1), a large number of gram-negative, yellowpigmented and rod-shaped bacteria have been found in a wide variety of plant materials. Previously, the present authors (2-4) reported the isolation of Pseudomonas perlurida and Ps. trifolii from paddy rice. These pseudomonads had been considered to be unique species because they metabolized carbohydrates fermentatively. Re-examination of these bacteria revealed, however, peritrichous flagellation not in conformity with the previous investigation. Therefore, taxonomic comparison was made of the strains employed previously and related bacteria. This paper deals with the correction of taxonomic position of pseudomonads mentioned above and characteristics of Erwinia herbicola which they were newly identified.

\section{MATERIALS AND METHODS}

Microorganisms. Strains employed in this study were those reported previously and freshly isolated from vegetables and fruit using nutrient agar plate with incubation at $30^{\circ}$. Gram-negative, yellow-pigmented, fermentative and rod-shaped bacteria were screened from the isolates. Sources of isolation are shown in Table 1 . The other related bacteria listed were used as controls.

Determination Methods. Determination techniques were mainly those described in the "Manual of Microbiological Methods" (5), "Manual of the Identification of Medical Bacteria" (6), and in the previous papers (3). Flagellation was ascertained by TODA's staining method (7) and by electron 
Table 1. Sources of tested bacteria.

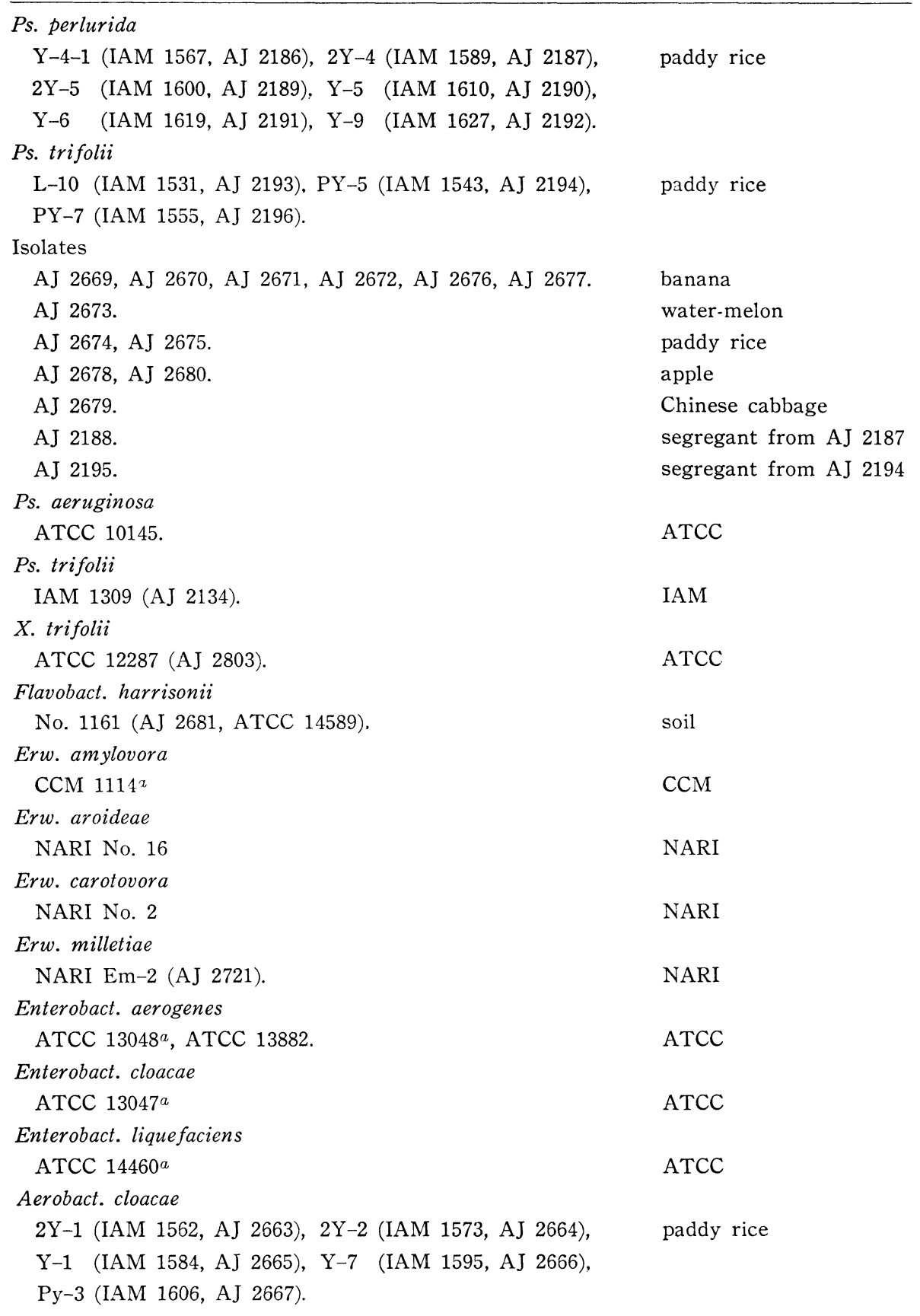


Table 1. Sources of tested bacteria. (continued)

S. marcescens

IAM 1105

IAM

Cit. freundii

ATCC $8090^{a}$

ATCC

Cit. intermedium

ATCC 6750

ATCC

E. coli

ATCC $11775^{a}$

ATCC

a Type or neotype culture.

IAM: The Institute of Applied Microbiology, Tokyo, Japan.

ATCC: American Type Culture Collection, Rockville, U.S.A.

NARI: National Agricultural Research Institute, Tokyo, Japan.

CCM : Czechoslovak Collection of Microorganisms, Brno, Czechoslovakia.

AJ: Central Research Laboratories, Ajinomoto Co., Inc., Kawasaki, Japan.

microscopy. Nitrate respiration and nucleoside phosphotransferase (NPTase) were tested by the methods reported previously $(8,9)$. Deoxyribonuclease (DNase) was detected by using Difco DNase medium (10), and pectolytic activity (pectinase) was tested by maceration of potato slice (11). Color of colonies was determined according to the Color Standard (12). All the tests were carried out at $30^{\circ}$ but pectinase was tested at $25^{\circ}$. Base composition (GC content) of deoxyribonucleic acid (DNA) was calculated by determining the melting temperature of $\operatorname{DNA}(13,14)$.

Computer Analysis. According to the method of SNEATH (15) computer analysis was made on the bacteria and similarity was obtained by the following formula:

$$
\mathrm{S}=\frac{\mathrm{N}_{\mathrm{s}}}{\mathrm{N}_{\mathrm{s}}+\mathrm{N}_{\mathrm{d}}}
$$

where $\mathrm{N}_{\mathrm{s}}=$ numbers of positive features shared; $\mathrm{N}_{\mathrm{d}}=$ numbers of features positive in one strain and negative in the other. As shown in Table 2, 69 features were used.

RESULTS

\section{General Characteristics.}

Strains tested were all gram-negative and rod-shaped. Cells were straight rods measuring 0.4 to 0.6 by 1.2 to 1.8 microns in average size. Diversity of the general characteristics was found among the strains as shown in Table 3. Twenty-nine strains presented in Table 3 were composed of 6 strains of Ps. perlurida (4), 3 strains of Ps. trifolii (4), 14 strains of the fresh 
Table 2. Features employed for computer analysis.

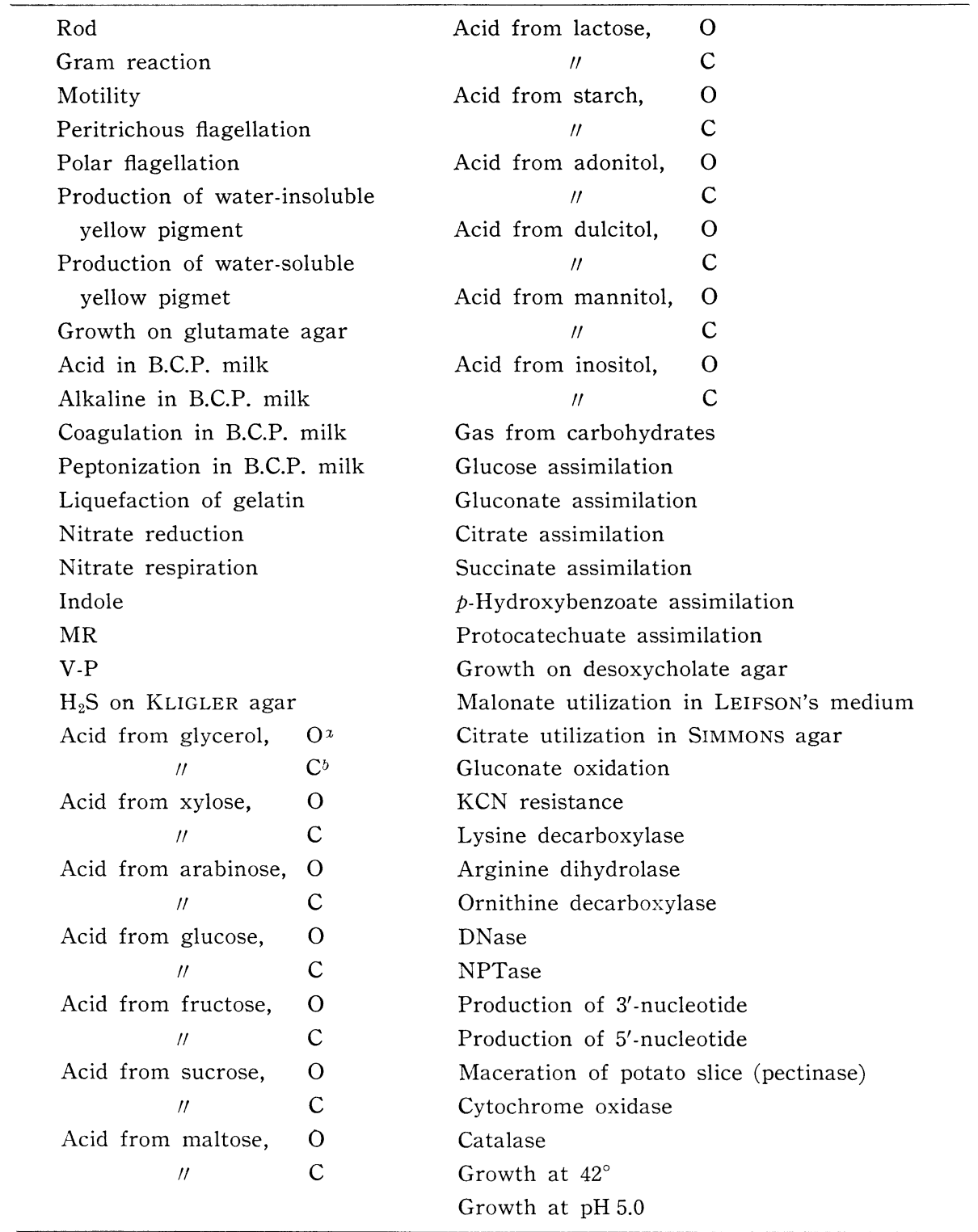

a Open; oxidative production of acid from carbohydrates.

$b$ Closed; fermentative production of acid from carbohydrates. 
Table 3. Diversity of characteristics of Erw. herbicola.

\begin{tabular}{|c|c|c|c|}
\hline & $\begin{array}{c}\text { Erw. herbicola } \\
\text { AJ } 2671 \\
\text { (typical strain) }\end{array}$ & $\begin{array}{l}\text { No. of strains } \\
\text { showed positive } \\
\text { reaction }\end{array}$ & $\begin{array}{c}\text { Per cent of } \\
\text { strains showed } \\
\text { positive reaction }\end{array}$ \\
\hline Rod & + & $29^{a}$ & 100 \\
\hline Gram-negative & + & 29 & 100 \\
\hline Motility & + & 25 & 86 \\
\hline Peritrichous flagellation & + & 25 & 86 \\
\hline $\begin{array}{l}\text { Production of water-insoluble } \\
\text { yellow pigment }\end{array}$ & + & 29 & 100 \\
\hline Growth on glutamate agar & + & 22 & 76 \\
\hline Acid in B.C.P. milk & + & 23 & 79 \\
\hline Alkaline in B.C.P. milk & - & 6 & 21 \\
\hline Coagulation in B.C.P. milk & + & 28 & 97 \\
\hline Peptonization in B.C.P. milk & - & 3 & 10 \\
\hline Liquefaction of gelatin & + & 29 & 100 \\
\hline Nitrate reduction ${ }^{b}$ & + & 26 & 90 \\
\hline Nitrate respiration & - & 0 & 0 \\
\hline Indole & + & 12 & 41 \\
\hline MR & + & 28 & 97 \\
\hline V-P & + & 25 & 86 \\
\hline $\mathrm{H}_{2} \mathrm{~S}$ in KLIGLER agar & - & 0 & 0 \\
\hline Hydrolysis of starch & - & 0 & 0 \\
\hline Acid from carbohydrates & & & \\
\hline glycerol, $\quad \mathrm{O}$ & + & 24 & 83 \\
\hline $\mathrm{C}$ & + & 14 & 48 \\
\hline xylose, & + & 28 & 90 \\
\hline "I & + & 28 & 90 \\
\hline arabinose, $\mathrm{O}$ & + & 29 & 100 \\
\hline 11 & + & 29 & 100 \\
\hline glucose, $\quad \mathrm{O}$ & + & 29 & 100 \\
\hline C & + & 29 & 100 \\
\hline fructose, $\quad \mathrm{O}$ & + & 29 & 100 \\
\hline "I & + & 29 & 100 \\
\hline sucrose, & + & 26 & 90 \\
\hline $\mathrm{C}$ & + & 25 & 86 \\
\hline maltose, & + & 29 & 100 \\
\hline $\mathrm{C}$ & + & 29 & 100 \\
\hline lactose, & + & 26 & 90 \\
\hline "I & + & 18 & 62 \\
\hline starch, & - & 0 & 0 \\
\hline II & - & 0 & 0 \\
\hline
\end{tabular}


Table 3. Divisity of characteristics of Erw. herbicola. (continued)

\begin{tabular}{|c|c|c|c|}
\hline & $\begin{array}{c}\text { Erw. herbicola } \\
\text { AJ } 2671 \\
\text { (typical strain) }\end{array}$ & $\begin{array}{l}\text { No. of strains } \\
\text { showed positive } \\
\text { reaction }\end{array}$ & $\begin{array}{c}\text { Per cent of } \\
\text { strains showed } \\
\text { positive reaction }\end{array}$ \\
\hline adonitol, $\mathrm{O}$ & + & 10 & 34 \\
\hline$\| \quad \mathrm{C}$ & + & 8 & 28 \\
\hline dulcitol, $\mathrm{O}$ & - & 4 & 14 \\
\hline$\| \quad \mathrm{C}$ & - & 0 & 0 \\
\hline mannitol, $\mathrm{O}$ & + & 29 & 100 \\
\hline$\prime \prime \quad \mathrm{C}$ & + & 29 & 100 \\
\hline inositol, $\mathrm{O}$ & + & 25 & 86 \\
\hline$\| \quad \mathrm{C}$ & + & 21 & 72 \\
\hline Gas from carbohydrates & - & 5 & 17 \\
\hline \multicolumn{4}{|l|}{ Assimilation } \\
\hline glucose & + & 26 & 90 \\
\hline gluconate & + & 28 & 97 \\
\hline citrate & + & 23 & 76 \\
\hline succinate & + & 28 & 97 \\
\hline$p$-hydroxybenzoate & - & 0 & 0 \\
\hline protocatechuate & + & 14 & 48 \\
\hline Growth on desoxycholate agar & + & 21 & 72 \\
\hline Malonate utilization & - & 13 & 45 \\
\hline $\begin{array}{l}\text { Citrate utilization on } \\
\text { SIMMONS agar }\end{array}$ & + & 26 & 93 \\
\hline Gluconate oxidation & - & 9 & 31 \\
\hline $\mathrm{KCN}$ resistance & - & 0 & 0 \\
\hline Lysine decarboxylase & - & 4 & 14 \\
\hline Arginine dihydrolase & - & 4 & 14 \\
\hline Ornithine decarboxylase & - & 4 & 14 \\
\hline Phenylalanine deamination & - & 0 & 0 \\
\hline DNase & - & 0 & 0 \\
\hline \multicolumn{4}{|l|}{ NPTase } \\
\hline $3^{\prime}$-nucleotide & - & 0 & 0 \\
\hline $5^{\prime}$-nucleotide & + & 29 & 100 \\
\hline Maceration of potato slice & - & 0 & 0 \\
\hline Cytochrome oxidase & - & 0 & 0 \\
\hline Catalase & + & 29 & 100 \\
\hline Growth at $42^{\circ}$ & - & 4 & 14 \\
\hline Growth at pH 5.0 & + & 19 & 65 \\
\hline
\end{tabular}

a Numbers include 6 strains of Ps. perlurida, 3 strains of Ps. trifolii, 14 strains of isolates, 4 strains of Aerobact. cloacae, and 1 strain of Flavobact. harrisonii reported by present authors, respectively; and 1 strain of Ps. trifolii IAM 1309.

$b$ Nitrate reduction in succinate-nitrate broth containing $0.02 \%$ yeast extract. 
isolates, 4 strains of Aerobacter cloacae (16), 1 strain of Flavobacterium harrisonii (17) and 1 strain of Ps. trifolii IAM 1309. The reason why such kinds of bacteria were included together will be described below. Of the 29 strains, 25 were motile and exhibited peritrichous flagellation consistently, but single lateral flagellum was also found in the stained preparation, as shown in Fig. 1. The strains of Ps. perlurida $2 \mathrm{Y}-4$ and $2 \mathrm{Y}-5$, and Ps. trifolii

A

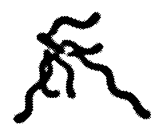

$3 \mu$

D

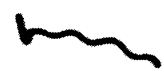

G

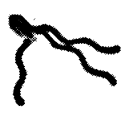

B

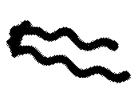

$E$

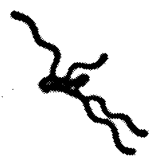

F

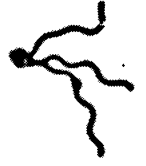

c

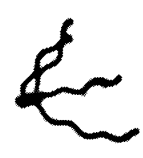

H

1

Fig. 1. Flagellation of Erw. herbicola.

Cells grown on nutrient agar slant for $18 \mathrm{hr}$ at $25^{\circ}$. Stained by ToDA's method.
A. Strain AJ 2196 (Ps. trifolii PY-7)
B. Strain AJ 2196 (Ps. tri folii PY-7)
C. Strain AJ 2672
D. Strain AJ 2194 (Ps. tri folii PY-5)
E. Strain AJ 2680
F. Strain AJ 2673
G. Strain AJ 2669
H. Strain AJ 2803
I. Strain AJ 2803 (X.trifolii ATCC 12287)
(X. trifolii ATCC 12287) 


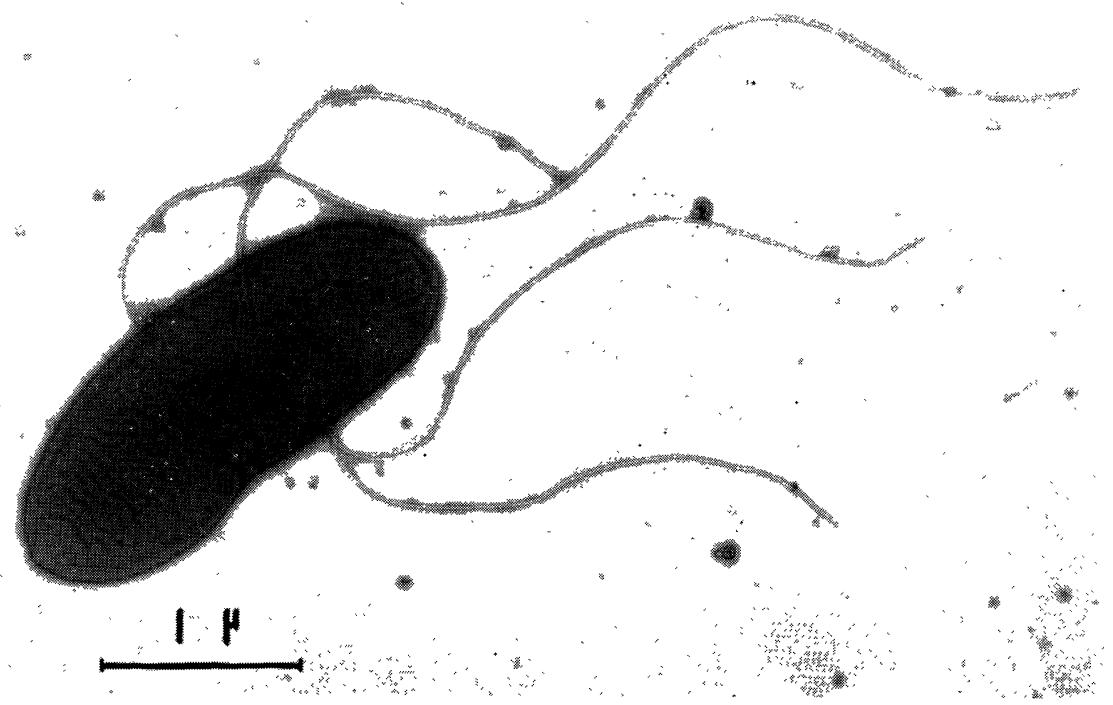

Fig. 2. Electron micrograph of Erw. herbicola AJ 2677.

Cell grown on nutrient agar slant for $18 \mathrm{hr}$ at $25^{\circ}$. Negatively stained.

L-10 had been motile when isolated in 1957, but motility was not found in 1967. The segregant AJ-2188 from Ps. perlurida $2 \mathrm{Y}-4$ also did not exhibit motility. Colonies on nutrient agar were circular, smooth and convex, and texture was butyrous. Color of colonies was versatile from dark yellow to pale yellowish brown as shown in Table 4. The isolates of AJ-2188 and AJ-2195 were color segregants from Ps. perlurida 2Y-4 and Ps. trifolii PY-5, respectively, and their color was slightly lighter than those of the original strains. Colonies on yeast extract-peptone agar were almost the same as those on nutrient agar, but the color was somewhat lighter than those on nutrient agar. On glutamate agar metallic sheen and slimy appearance were observed. Gelatin was slowly liquefied. B.C.P. milk was acidified and coagulated, but was alkaline in some cases. All the strains reduced nitrate to nitrite in succinate-nitrate broth but some showed scanty growth. Much less number, 15 strains, reduced nitrate to nitrite in nitrate broth, and 27 strains did in succinate-nitrate broth supplemented with $0.02 \%$ yeast extract. This may be ascribed to selective assimilation of nitrogenous compounds by these bacteria. All the strains failed to grow anaerobically by nitrate respiration. Almost all the strains gave a positive reaction on V-P test, and about half produced indole. Hydrogen sulfide was not produced on KLIGLER agar. 
Table 4. Versatility of coloration of colonies.

\begin{tabular}{l|c|c}
\hline & No. of strains & $\%$ \\
\hline Dark yellow & 6 & 20 \\
Dull yellow & 9 & 31 \\
Pale yellow & 5 & 17 \\
Reddish yellow & 7 & 24 \\
Yellowish gray & 1 & 3 \\
Pale yellowish brown & 1 & 3 \\
\hline
\end{tabular}

According to HUGH and LEIFSON's method, they all produced acid fermentatively from various carbohydrates. They could develop anaerobically in the presence of glucose. Some strains produced reducing substance from gluconate. Starch was not hydrolyzed. Glucose, gluconate, citrate, succinate and protocatechuate were utilized as the sole source of carbon with ammoniacal nitrogen, though some exceptions were found. Of the 29 strains, 21 grew on desoxycholate agar, 13 utilized malonate and 26 assimilated citrate on Simmons agar. All the strains produced 5 '-isomer of nucleotide by NPTase. Cytochrome oxidase and urease were negative. DNase was not found within $24 \mathrm{hr}$ but indefinite zones were seen after long incubation in some cases. On the contrary, Serratia marcescens gave a large clear zone within $24 \mathrm{hr}$. Catalase was positive in all the strains.

\section{Computer Analysis.}

All the strains resemble one another with similarity of $60 \%$ and were divided into distinct 3 clusters as shown in Fig. 3. Clusters of I and II were closely related, but cluster III was somewhat different from other two. Members of cluster I were biochemically more active than those of clusters of II and III. These bacteria also showed similarity to the members of Enterobacteriaceae. Erw. carotovora NARI No. 2, Erw. amylovora CCM 1114, Erw. milletiae NARI Em-2 and Aerobact. cloacae 2Y-2, Y-1, Y-7 and Py-3 were included in cluster III, but Ps. aeruginosa ATCC 10145 differed distinctly from clusters of I, II and III. Aerobact. cloacae 2Y-2, Y-1, Y-7 and Py-3 produced gas from glucose, grew at $42^{\circ}$, and showed positive reactions of lysine decarboxylase, arginine dihydrolase and ornithine decarboxylase. However, they produced $5^{\prime}$-nucleotide by NPTase and reduced nitrate to nitrite but could not grow by nitrate respiration.

\section{DISCUSSION}

The strains of Ps. perlurida and Ps. trifolii reported previously by the present authors (2-4) exhibited the same bactericlogical characteristics as 


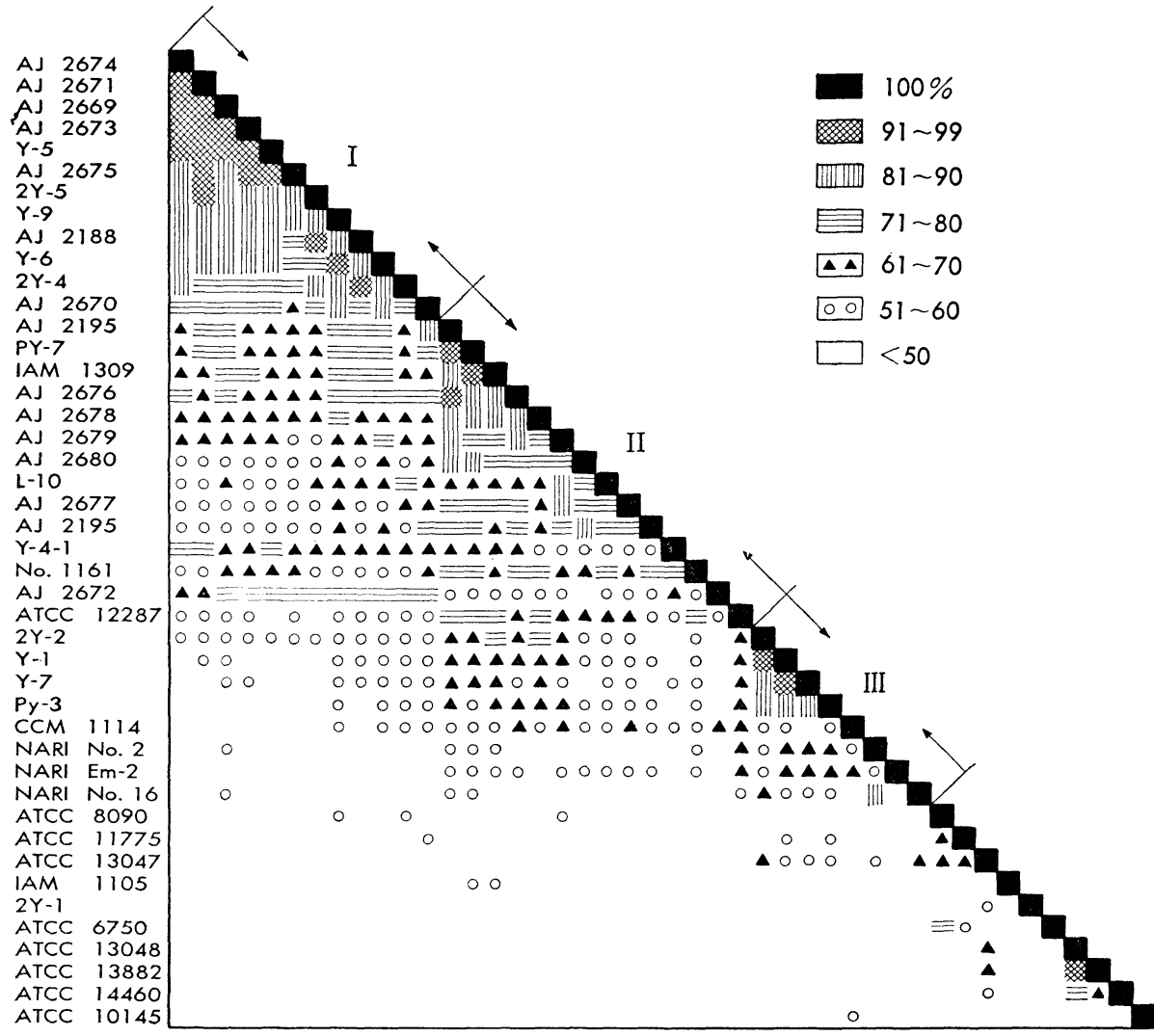

Fig. 3. Diagram of $\mathrm{S}$ value.

described, and they were included in a single species pattern on the basis of computer analysis. However, they should be removed from the genus Pseudomonas and transferred to Enterobacteriaceae because of peritrichous flagellation and of fermentative cleavage of carbohydrates. Furthermore, base composition of DNA of the isolate AJ-2195 and Aerobact. cloacae 2Y-2 were 52.0 and 52.2, respectively. These correspond to those of the members of Enterobacteriaceae (18). They should be excluded from the genera of animal origin because they are widely distributed in plant materials.

Meanwhile, these bacteria appear to be quite similar to Bacterium herbicola aureum Düggeli, 1904, by comparison with the original description. After the work of DüGGELI (1), several bacteria taxonomically related to Bact. herbicola aureum have been reported as presented in Table 5 and the nomenclature of this species has been complicated as shown in Table 6. Huss (19) isolated Ps. trifolii from plant materials, and MACK (20) concluded that 
both species of Bact. herbicola aureum and Ps. trifolii were identical with each other by a comparative study, and proposed Bact. herbicola or Flavobact. herbicola according to Bergey's system. JAMES (21) isolated a similar bacterium from wheat and proposed a new combination, Xanthomonas trifolii, on the coloration of colonies and flagellation. Further, BILLING and BAKER (22) found Erwinia-like organisms in plants.

A reason for the complicated nomenclature of these bacteria might be ascribed to the description of flagellation. DÜGGELI ( 1 ) reported motility of Bact. herbicola aureum but not its flagellation. HUSS (19) described flagellation of Ps. trifolii as polar with a sketch. MAcK (20) also reported polar flagellation of Bact. herbicola but micrograph revealed lateral flagellation. JAMES (21) described motility of $X$. trifolii as follows: "In nutrient broth culture they were actively motile. Most cells had one polar flagellum, but a few had two and a few four near one pole". The strain used in his work (X. trifolii ATCC 12287), however, exhibited peritrichous flagellation on the observation of the present authors as shown in Fig. 1. Electron micrograph of Bact. herbicola taken by HOUWINK and VAN ITERSON (23) revealed peritrichous flagellation. HOLDING (24) described flagellation of Bact. herbicola as peritrichous. Flagellation of $X$. uredovorans which is biochemically similar to Bact. herbicola aureum was reported as peritrichous by HAYWARD and HoDGKISS (25). From the report of HouwINK and VAN ITERSON (23) that young cells of Bact. herbicola may possess smaller numbers of flagella compared with old ones and from the observation of the present authors, the workers in early days must have misinterpreted the flagellation of such bacteria. Biochemical characteristics of bacteria that appeared in the past literature were almost the same as shown in Table 5. From comparison, the authors consider that the strains used by DÜGGELI (1), Huss (19), MACK (20), JAMES (21), and by BILLING and BAKER (22), and employed in the present study should be included together in the same species pattern, though some intraspecific differences could be found.

Another complication in this nomenclature has been the specific epithet, and both "herbicola" and "trifolii" have been used as shown in Table 6 . DÜGGELI (1) reported the species in trinominal but did not describe in binominal. JAMES $(21)$ pointed out the inadequateness of "herbicola" because the trinominal had meant the variety of bacteria, and stressed the misuse of MACK (20) that she was not concerned about dropping the third word of trinominal. DYE (26) concluded that $X$. trifolii reported by JAMES should be placed in the genus Erwinia on the basis of peritrichous flagellation and proposed a new combination, Erw. herbicola (Düggeli). However, BUCHANAN et al. (27) pointed out the invalid publication of Bact. herbicola aureum because of trinominal naming and valid publication of Bact. herbicola by GEILINGER (28). They described a correct combination of Erw. herbicola (Geilinger) Dye. The genus Erwinia has been well known as pathogens to many kinds of plants, and the pathogenicity has been concerned with 
Table 5. Comparison of Bact. herbicola

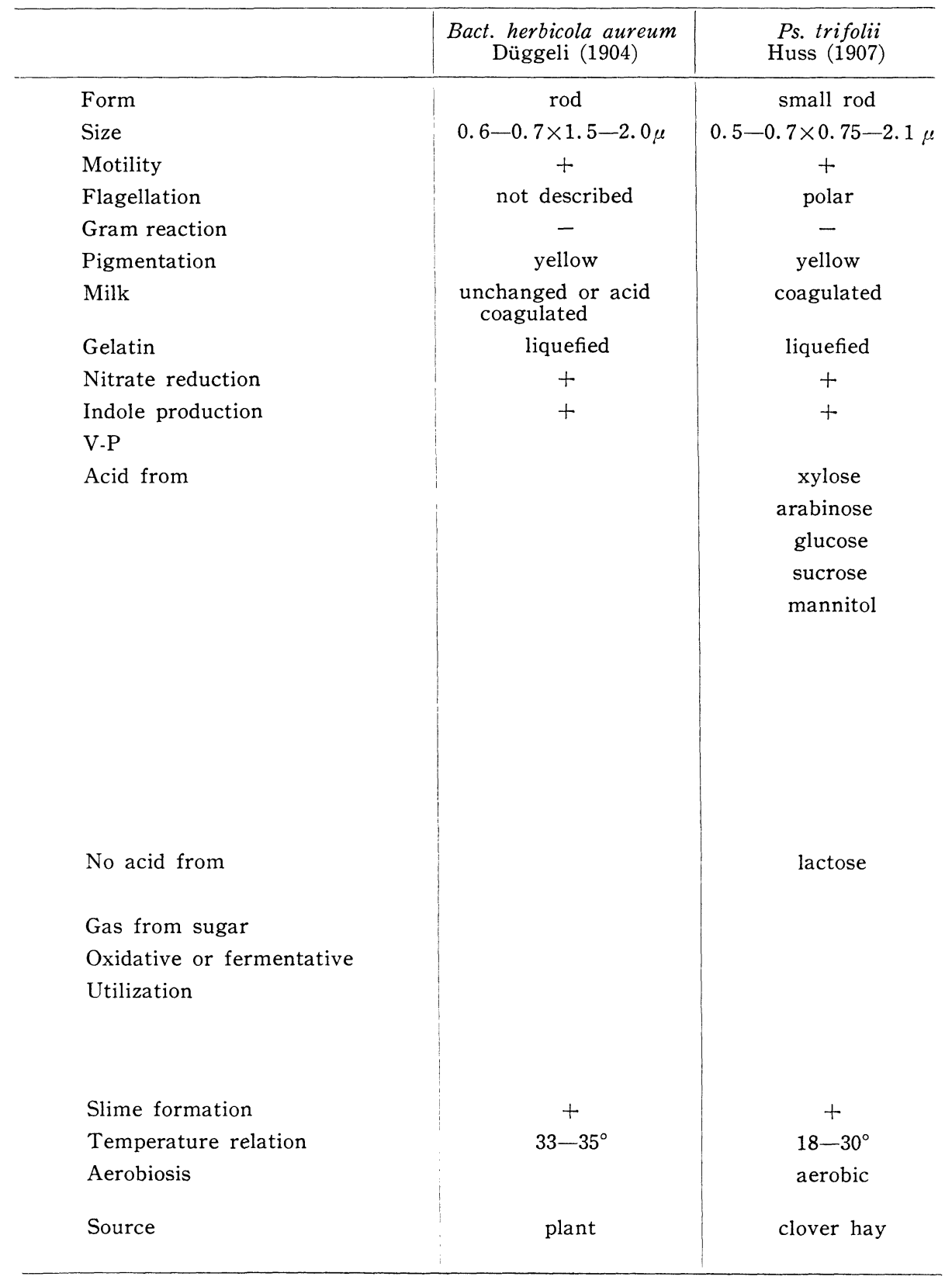


aureum and related bacteria.

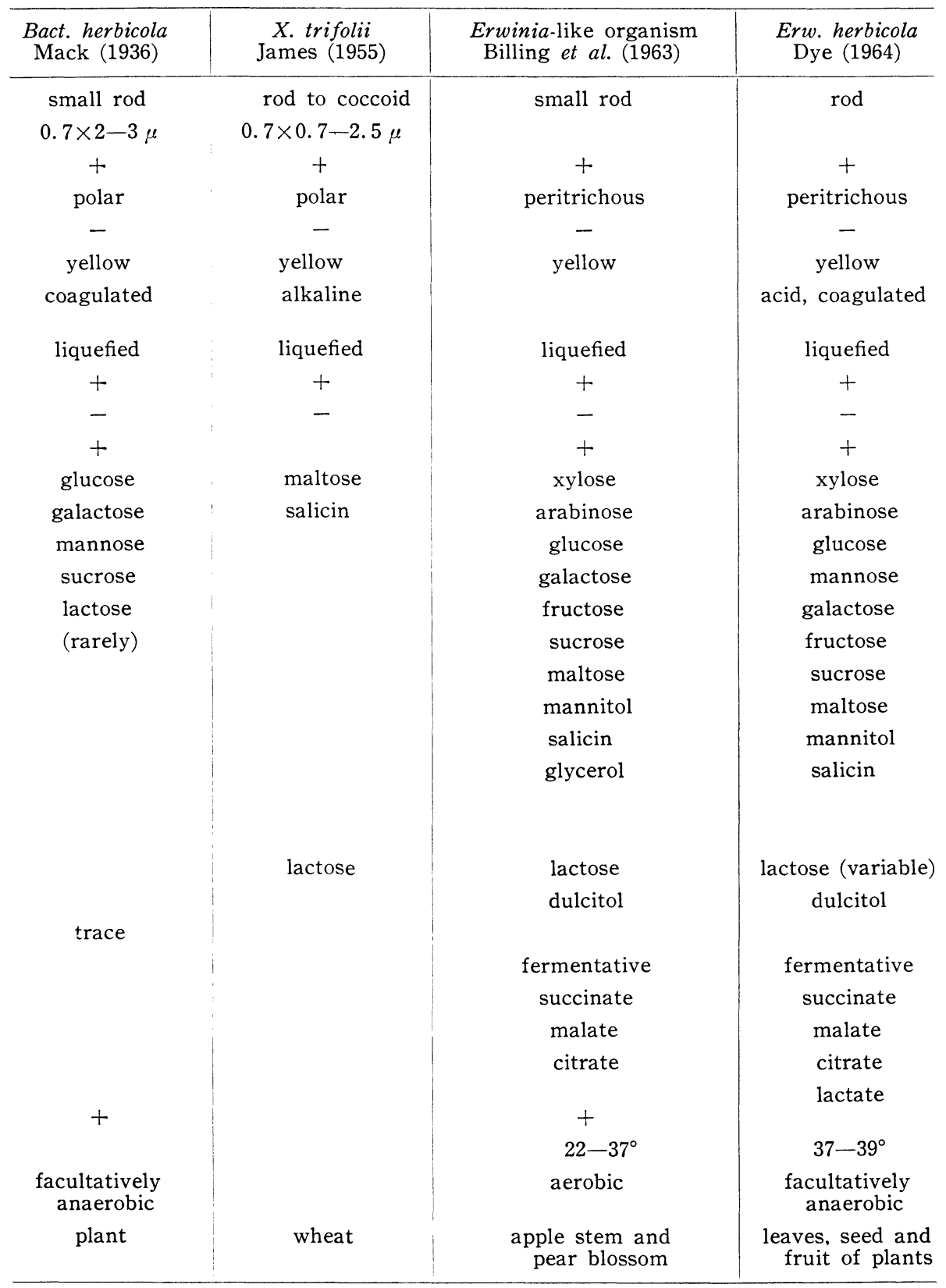


Table 6. Nomenclature of Erw. herbicola.

\begin{tabular}{|c|c|c|}
\hline 1904 & $\begin{array}{c}\text { Bact. herbicola aureum } \\
{[\text { DÜGGELI] }]^{a}(1)}\end{array}$ & \\
\hline 1907 & & Ps. trifolii [Huss] (19) \\
\hline 1921 & Bact, herbicola [GEILINGER] (28) & \\
\hline 1923 & & $\begin{array}{l}\text { Flavobact. trifolium (Huss) } \\
\text { [BERGEY et al.] } \\
\text { [Bergey's Manual, } 1 \text { st ed.] (31) }\end{array}$ \\
\hline 1927 & $\begin{array}{l}\text { Ps. herbicola (Geilinger) } \\
\text { [DE'RossI] (29) }\end{array}$ & \\
\hline 1934 & & $\begin{array}{l}\text { Flavobact. trifolii (Huss) } \\
\text { Bergey et al. } \\
\text { [Bergey's Manual, } 4 \text { th ed.] (32) }\end{array}$ \\
\hline 1936 & Bact. herbicola [MACK] (20) & \\
\hline 1938 & & $\begin{array}{l}\text { Ps. trifolii Huss } \\
\text { [Bergey's Manual, } 5 \text { th ed.] (33) }\end{array}$ \\
\hline 1948 & & $\begin{array}{l}\text { Ps. trifolii Huss } \\
\text { [Bergey's Manual, } 6 \text { th ed.] (34) }\end{array}$ \\
\hline 1955 & & $X$. trifolii (Huss) [JAMES] (21) \\
\hline 1957 & & $\begin{array}{l}\text { Ps. trifolii Huss } \\
\text { [Bergey's Manual, } 7 \text { th ed.] (35) }\end{array}$ \\
\hline 1959 & $\begin{array}{l}\text { Ps. herbicola (Burri et Düggeli) } \\
\text { [KRASSILNIKOV's Manual] }(30)\end{array}$ & \\
\hline 1960 & Bact. herbicola [HoLDING] (24) & \\
\hline 1961 & & $\begin{array}{l}\text { X. trifolii (Huss) James } \\
\text { [PRÉVOT's Manual] (36) }\end{array}$ \\
\hline 1963 & $\begin{array}{l}\text { Erwinia-like organisms } \\
\text { [BILLING and BAKER] }\end{array}$ & $\begin{array}{l}\text { Ps. trifolii Huss } \\
\text { [IIZUKA and Komagata] (4) }\end{array}$ \\
\hline 1964 & $\begin{array}{l}\text { Erwinia herbicola (Düggeli) } \\
\text { [DYE] }(26)\end{array}$ & \\
\hline 1966 & $\begin{array}{l}\text { Erwinia herbicola (Geilinger) Dye } \\
\text { [Index Bergeyana] }(27)\end{array}$ & \\
\hline 1967 & $\begin{array}{l}\text { Erw. herbicola (Geilinger) Dye } \\
\text { [KomAGATA et al. }]\end{array}$ & \\
\hline
\end{tabular}

a Names in parentheses indicate the investigators.

identification of the species of this genus. As a strain of Erw. milletiae pathogenic to Japanese wisteria seems to be included in the species pattern of the tested bacteria, as shown in Fig. 3 and Table 7, plant pathogenicity of these bacteria is expected. Therefore, all the strains employed in the present work were inoculated into Japanese wisteria, but the symptoms of disease were not recognized. Further, JAMEs (21) and DYE (26) did not find pathogenicity in $X$. trifolii and Erw. herbicola, respectively, in spite of inoculation test.

From the viewpoint of determination, it is probably reasonable to conclude that these bacteria should be placed in the genus Erwinia on the basis of flagellation, biochemical characteristics and habitat regardless of plant patho- 
Table 7. Comparison of Erw. herbicola and related bacteria.

\begin{tabular}{|c|c|c|c|c|c|c|c|c|c|}
\hline & 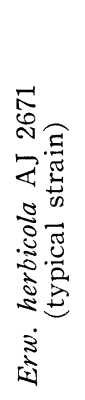 & 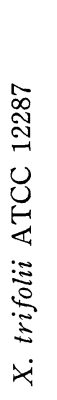 & 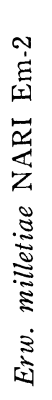 & 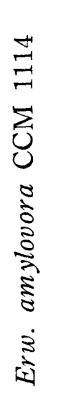 & 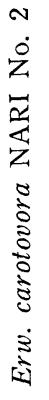 & 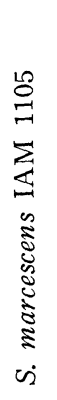 & 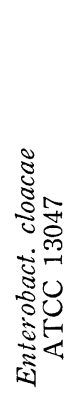 & 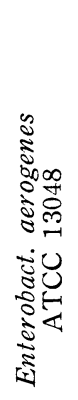 & 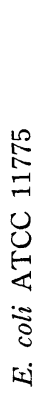 \\
\hline Gram-negative rod & + & + & + & + & + & + & + & + & + \\
\hline Peritrichous flagella & + & + & + & + & + & + & + & - & + \\
\hline Yellow pigmentation & + & + & + & - & - & - & - & - & - \\
\hline Coagulation of milk & + & + & - & - & + & + & + & + & + \\
\hline Liquefaction of gelatin & + & + & + & + & + & + & + & - & - \\
\hline Nitrate reduction & + & + & + & - & + & + & + & + & + \\
\hline Nitrate respiration & - & - & - & - & + & + & + & + & + \\
\hline Indole & + & - & - & - & - & - & - & - & + \\
\hline V-P & + & + & + & + & + & + & + & + & - \\
\hline Citrate & + & + & + & - & + & + & + & + & - \\
\hline \multirow{2}{*}{$\begin{array}{ll}\text { Glucose, } & \text { O. } \\
& \text { C. }\end{array}$} & + & + & + & + & + & + & + & + & + \\
\hline & + & + & + & + & + & + & + & + & + \\
\hline \multirow[t]{2}{*}{ Lactose, $\mathrm{O}$} & + & - & - & - & + & - & + & + & + \\
\hline & + & - & - & - & + & - & + & + & + \\
\hline \multicolumn{10}{|l|}{ NPTase test } \\
\hline $3^{\prime}$-nucleotide & - & - & - & - & - & - & $t$ & + & + \\
\hline $5^{\prime}$-nucleotide & + & + & + & - & - & + & - & - & - \\
\hline DNase & - & - & - & - & - & + & - & - & - \\
\hline Pectinase & - & - & - & - & + & - & - & - & - \\
\hline Growth at $42^{\circ}$ & - & - & - & - & + & + & + & + & + \\
\hline
\end{tabular}

genicity. From such a consideration and nomenclature described by BUCHANAN et al. (27), the authors identified the following strains with Erw. herbicola: Ps. perlurida Y-4-1, 2Y-4, 2Y-5, Y-5, Y-6 and Y-9; Ps. trifolii L-10, PY-5 and PY-7; and the isolates AJ-2669, -2670, -2671, -2672, -2676, -2677, -2673, $-2674,-2675,-2678,-2680,-2679,-2188$ and -2195 . Further, the following strains were also included in Erw. herbicola on the flagellation and biochemical characteristics: Ps. trifolii IAM 1309, X. trifolii ATCC 12287, Flavobact. harrisonii No. 1161 (AJ 2681, ATCC 14589) and Erw. milletiae NARI Em-2. The strains of Aerobact. cloacae 2Y-2, Y-1, Y-7 and Py-3 were also included 
in Erw. herbicola because of production of $5^{\prime}$-nucleotide by NTPase and of inability to grow by nitrate respiration, although they were somewhat different from the bacteria mentioned above in respects to production of gas from carbohydrates, growth at $42^{\circ}$ and positive reactions of lysine decarboxylase, arginine dihydrolase and ornithine decarboxylase. The strains of Erw. herbicola can be easily differentiated from the other related bacteria in Enterobacteriaceae on the basis of inability to grow by nitrate respiration, NPTase and other biochemical characteristics as shown in Table 7. The detailed study concerning the differentiation among the species of the genus Erwinia will be reported in the following paper.

\section{DESCRIPTION}

\section{Erwinia herbicola (Geilinger) Dye}

Synonyms :

Bacterium herbicola aureum Düggeli, 1904 (1). .

Pseudomonas trifolii Huss, 1907 (19).

Bacterium herbicola Geilinger, 1921 (28).

Flavobacterium trifolium (Huss) Bergey et al., 1923 (31).

Pseudomonas herbicola (Geilinger) de'Rossi, 1927 (29).

Bacterium herbicola (Düggeli) Mack, 1936 (20).

Xanthomonas trifolii (Huss) James, 1955 (21).

Pseudomonas herbicola (Burri et Düggeli) Krassilnikov, 1959 (30).

Erwinia herbicola (Düggeli) Dye, 1964 (26).

Rods, 0.4 to 0.6 by 1.2 to 1.8 microns. Occurring singly or in pairs, not in chain. Motile with peritrichous flagella. Non-motile varieties are found. Gram-negative. Spore not formed.

Nutrient agar colonies: Circular, smooth, entire, raised, glistening, opalescent, dark yellow, butyrous. (Variation: Dull yellow, pale yellow, reddish yellow, yellowish gray or pale yellowish brown.)

Yeast extract-peptone agar colonies: Circular, smooth, entire, raised, glistening, opalescent, reddish yellow, butyrous. (Variation: Dull yellow, dark yellow, pale pellow, yellowish brown or yellowish gray; irregular form; slightly rough surface; and erose margin.)

Nutrient agar slant: Growth moderate, filiform, glistening, opalescent, dull yellow. (Variation: Dark yellow, yellowish orange or pale yellowish brown.)

Yeast extract-peptone agar slant: Growth moderate, filiform, glistening, opalescent, reddish yellow. (Variation: Dull yellow, pale yellowish brown, yellowish gray or pale yellow.)

Glutamate agar slant: Growth moderate, fliform, glistening, metallic sheen, dull yellow. (Variation: Scanty or no growth; rough or pitted surface; viscid or fluid texture; yellowish gray, reddish yellow, pale yellow or white.)

Nutrient broth: Fragile pellicle, siightly turbid. (Variation: No surface growth, moderately turbid.) 
Glutamate broth: Moderately turbid. (Variation: Flocculent pellicle; or no growth.)

Nutrient gelatin stab: Slow liquefaction.

B.C.P. milk: Acid coagulation. (Variation: Alkaline or neutral, soft coagulum ; peptonization.)

Nitrite produced from nitrate in nitrate broth and succinate-nitrate broth. (Variation: No production in nitrate broth.)

Nitrate respiration: Negative.

Indole produced. (Variation: No production.)

Hydrogen sulfide not produced in KLIGLER agar.

Starch not hydrolyzed.

MR test: Positive. (Variation: Negative.)

V-P test: Positive. (Variation: Negative.)

Acid but no gas is produced from glycerol, xylose, arabinose, glucose, fructose, sucrose, maltose, lactose, mannitol and inositol in both aerobic and anaerobic conditions, but not from dulcitol and starch according to HUGH and LEIFSON's method. (Variation: No anaerobic production of acid from glycerol, lactose and inositol; no production of acid from glycerol, sucrose, xylose and inositol in both aerobic and anaerobic conditions; production of acid from dulcitol; production of gas from xylose, arabinose, glucose, fructose, maltose and sucrose.)

Reducing substance is not produced from gluconate. (Variation: Production of reducing substance.)

Glucose, gluconate, citrate, succinate and protocatechuate are utilized as the sole carbon source with ammoniacal nitrogen but $p$-hydroxybenzoate is not. (Variation: No utilization.)

Malonate is not utilized in LeIFson's medium. (Varition: Utilization.)

Citrate is utilized in Simmons agar. (Variation: No utilization.)

Desoxycholate agar: Growth. (Variation: No growth.)

Nucleoside phosphotransierase: Positive. (5'-Nucleotide is produced.)

Lysine decarboxylase: Negative. (Variation: Positive.)

Arginine dihydrolase: Negative. (Variation: Positive.)

Ornithine decarboxylase: Negative. (Variation: Positive.)

Cytochrome oxidase : Negative.

Catalase: Positive.

Maceration of potato slice: Negative.

Good growth between $20^{\circ}$ and $35^{\circ}$. No gowth at $15^{\circ}$ and $42^{\circ}$. (Variation: Growth at $15^{\circ}$ and $42^{\circ}$.)

Growth at pH 5.0: Growth. (Variation: No growth.)

Sources: Paddy rice, fruit, soil, etc. Widely distributed in plant materials.

The typical strain, Erw. herbicola AJ 2671, has been depssited with The Institute of Applied Microbiology, University of Tokyo. 
After completion of this manuscript, GRAHAM and HODGKISS (37) reported the identity of gram-negative, yellow-pigmented, fermentative bacteria isolated from plants and animals, and included such bacteria in Erw. herbicola.

The authors wish to thank Dr. Tominaga, National Agricultural Research Institute, for the determination of plant pathogenicity of the bacteria, and also Mr. Kobata of this Institute for calculation of computer analysis.

\section{REFERENCES}

1) M. DüGGELI, Zentr. Bakteriol., Abt. II, 13, 56 (1904).

2) K. Komagata, J. Gen. Appl. Microbiol., 7, 282 (1961).

3) H. Iizuka and K. Komagata, J. Gen. Appl. Microbiol., 9, 73, 83 (1963).

4) H. Iizuka and K. Komagata, J. Agr. Chem. Soc. Japan., 37, 71 (1963).

5) M.J. Pelczar, Jr., Manual of Microbiological Methods, McGraw-Hill, New York (1957).

6) S.T. Cowan and K.J. Steel, Manual for the Identification of Medical Bacteria, Cambridge University Press, London (1965).

7) T. Toda, Nihon Iji Shinpo, No. 283, 113 (1928).

8) K. Komagata, H. Iizuka and M. Takahashi, J. Gen. Appl. Microbiol., 11, 191 (1965).

9) K. Komagata and Y. Tamagawa, J. Gen. Appl. Microbiol., 12, 191 (1966).

10) N.W. Rothberg and M.N. SWArtz, J. Bacteriol., 90, 294 (1965).

11) B.M. Gibbs and F.A. Skinner, Identification Methods for Microbiologists, Part A. Academic Press, London (1966).

12) Nihon Shikisai Kenkyujo, Guide to Color Standard, Nihon Shikisai-sya, Tokyo (1964).

13) J. Marmur, J. Mol. Biol., 3, 208 (1961).

14) J. Marmur and P. Doty, J. Mol. Biol., 5, 109 (1962).

15) P.H.A. Sneath, J. Gen. Microbiol., 17, 184, 201 (1957).

16) H. Iızuka, K. Komagata, and C. Uchino, J. Agr. Chem. Soc. Japan., 37, 701 (1963).

17) K. Mitsugi, K. Komagata, M. Takahashi, H. Iizuka and H. Katagiri, Agr. Biol. Chem. (Tokyo)., 28, 586 (1964).

18) L.R. Hill, J. Gen. Microbiol., 44, 419 (1966).

19) H. Huss, Zentr. Bakteriol., Abt. II, 19, 50, 149 (1907).

20) E. MAck, Zentr. Bakteriol., Abt. II, 95, 218 (1936).

21) N. James, Canad. J. Microbiol., 1, 479 (1955).

22) E. Billing and L.A. Baker, J. Appl. Bacteriol., 26, 58 (1963).

23) A.L. Houwink and W. van Iterson, Biochem. Biophys. Acta, 5, 10 (1950).

24) A.J. Holding, J. Appl. Bacteriol., 23, 515 (1960).

25) A.C. Hayward and W. Hodgkiss, J. Gen. Microbiol., 26, 133 (1961).

26) D.W. Dye, New Zealand J. Sci., 7, 261 (1964).

27) R.E. Buchanan, J.G. Holt and E.F. Lessel, Jr., Index Bergeyana, Williams and Wilkins, Baltimore (1966).

28) H. Geilinger, Mitt. Lebensm. Hyg. Bern, 12, 49, 105, 231 (1921).

29) G. DE' Rossi, Microbiologia agraria e tecnica. Torino, p. 1 (1927), cited from reference 27. 
30) N.A. Krassilnikov, Diagnostik der Bakterien und Actinomyceten, Gustav Fischer, Jena (1959).

31) D.H. Bergey, Bergey's Manual of Determinative Bacteriology, 1st ed., Williams and Wilkins, Baltimore (1923).

32) D.H. Bergey, Bergey's Manual of Determinative Bacteriology, 4th ed., Williams and Wilkins, Baltimore (1934).

33) D.H. Bergey, R.S. Breed, E.G.D. Murray and A.P. Hitchens, Bergey's Manual of Determinative Bacteriology, 5th ed., Williams and Wilkins, Baltimore (1938).

34) R.S. Breed, E.G.D. Murray and A.P. Hitchens, Bergey's Manual of Determinative Bacteriology, 6th ed., Williams and Wilkins, Baltimore (1948).

35) R.S. Breed, S.G.D. Murray and N.R. Smith, Bergey's Manual of Determinative Bacteriology, 7th ed., Williams and Wilkins, Baltimore (1957).

36) A.R. Prévot, Traite de Systématique Bactérinne, Tome 2. Dunod, Paris (1961).

37) D.C. Graham and W. Hodgkiss, J. Appl. Bacteriol., 30, 175 (1967). 